\title{
Prevalence of bortezomib-resistant constitutive NF-kappaB activity in mantle cell lymphoma
}

\author{
David T Yang1, Ken H Young ${ }^{2,4}$, Brad S Kahl ${ }^{3,4}$, Stephanie Markovina ${ }^{1,5}$ and \\ Shigeki Miyamoto*1,4
}

Address: ${ }^{1}$ Department of Pharmacology, University of Wisconsin School of Medicine and Public Health, Madison, USA, ${ }^{2}$ Department of Pathology and Laboratory Medicine, University of Wisconsin School of Medicine and Public Health, Madison, USA, ${ }^{3}$ Department of Medicine, University of Wisconsin School of Medicine and Public Health, Madison, USA, ${ }^{4}$ Paul P. Carbone Comprehensive Cancer Center, University of Wisconsin, Madison, USA and ${ }^{5}$ Program in Cellular and Molecular Biology and Medical Scientist Training Program, University of Wisconsin School of Medicine and Public Health, Madison, USA

Email: David T Yang - dtyang@wisc.edu; Ken H Young - KYoung2@uwhealth.org; Brad S Kahl - bsk@medicine.wisc.edu; Stephanie Markovina - smarkovina@wisc.edu; Shigeki Miyamoto* - smiyamot@wisc.edu

* Corresponding author

Published: 19 May 2008

Molecular Cancer 2008, 7:40
Received: 2 April 2008

Accepted: 19 May 2008

This article is available from: http://www.molecular-cancer.com/content/7/1/40

(c) 2008 Yang et al; licensee BioMed Central Ltd.

This is an Open Access article distributed under the terms of the Creative Commons Attribution License (http://creativecommons.org/licenses/by/2.0), which permits unrestricted use, distribution, and reproduction in any medium, provided the original work is properly cited.

\begin{abstract}
Background: The proteasome inhibitor bortezomib can inhibit activation of the transcription factor NF- $\kappa B$, a mechanism implicated in its anti-neoplastic effects observed in mantle cell lymphoma (MCL). However, NF-KB can be activated through many distinct mechanisms, including proteasome independent pathways. While MCL cells have been shown to harbor constitutive NF$\kappa B$ activity, what fraction of this activity in primary $M C L$ samples is sensitive or resistant to inhibition by bortezomib remains unclear.

Results: Proteasome activity in the EBV-negative MCL cell lines Jeko-I and Rec-I is inhibited by greater than $80 \%$ after exposure to $20 \mathrm{nM}$ bortezomib for 4 hours. This treatment decreased NF$\kappa B$ activity in Jeko-I cells, but failed to do so in Rec-I cells when assessed by electrophoretic mobility shift assay (EMSA). Concurrently, Rec-I cells were more resistant to the cytotoxic effects of bortezomib than Jeko-I cells. Consistent with a proteasome inhibitor resistant pathway of activation described in mouse B-lymphoma cells (WEHI23I) and a breast carcinoma cell line (MDAMB-468), the bortezomib-resistant NF-KB activity in Rec-I cells is inhibited by calcium chelators, calmodulin inhibitors, and perillyl alcohol, a monoterpene capable of blocking L-type calcium channels. Importantly, the combination of perillyl alcohol and bortezomib is synergistic in eliciting Rec-I cell cytotoxicity. The relevance of these results is illuminated by the additional finding that a considerable fraction of primary MCL samples (8 out of 10 ) displayed bortezomib-resistant constitutive NF-KB activity.
\end{abstract}

Conclusion: Our findings show that bortezomib-resistant NF- $\kappa B$ activity is frequently observed in $\mathrm{MCL}$ samples and suggest that this activity may be relevant to $M C L$ biology as well as serve as a potential therapeutic target. 


\section{Background}

Mantle cell lymphoma (MCL) is an aggressive B-cell nonHodgkin lymphoma genetically characterized by the $\mathrm{t}(11 ; 14)(\mathrm{q} 13 ; \mathrm{q} 32)$ translocation with overexpression of cyclin D1. [1] It typically presents as advanced disease in men over 60 years of age and accounts for approximately $5 \%$ of all non-Hodgkin lymphoma (NHL) with an incidence of approximately 3,000 cases per year in the United States [2-5]. MCL remains a therapeutic challenge, having the worst 5-year survival of any lymphoma subtype in the NHL classification project and a median survival of only 3 or 4 years [6-15].

The need for new treatment strategies has led to the development of a novel class of pharmacologic agents, the proteasome inhibitors. After demonstrating activity in patients with refractory multiple myeloma with a manageable toxicity profile, bortezomib (Velcade; Millenium Pharmaceuticals Inc, Cambridge, MA), a reversible inhibitor of chymotryptic-like activity in the 26S proteasome, was the first agent of this class to be approved for clinical use [16-20]. When administered as a single agent in relapsed MCL, response rates of $29-48 \%$ have been demonstrated [21-24]. The efficacy of bortezomib in treating previously refractory cases of MCL is believed to involve multiple signaling pathways, and among them, the nuclear factor $\kappa \mathrm{B}(\mathrm{NF}-\kappa \mathrm{B})$ pathways [25-27].

NF- $\kappa B$ is a family of related transcription factors including

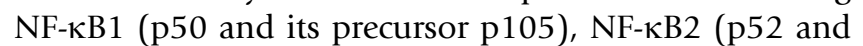
its precursor p100), p65 (RelA), RelB, and cRel that are typically found as homo- or heterodimers. This family of transcription factors is unique in its capacity to coordinate transcription of a diverse array of genes, including those involved in cell proliferation and resistance to apoptosis, thereby opening avenues for malignant cell growth [2831]. NF- $\kappa B$ has been implicated as an important mediator of malignant cell growth and survival in MCL. While most non-malignant cells contain inactive NF- $\mathrm{NB}$ complexes sequestered in their cytoplasm, constitutive activation of NF- $\kappa B$ has been frequently observed in both MCL cell lines and primary MCL samples and accordingly, inhibition of this constitutive activation has been shown to elicit cell cycle arrest and cell death $[25,26,32,33]$.

There are multiple distinct signaling pathways that lead to activation of NF-кB. The best characterized mechanisms of inducible NF- $\kappa$ B activation are termed "canonical" and "non-canonical". The canonical pathway is initiated through receptor binding by ligands such as tumor necrosis factor alpha or lipopolysaccharide. This activates a signaling cascade involving the phosphorylation of the NF-

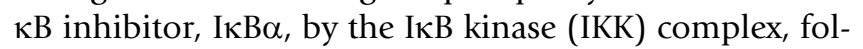
lowed by its ubiquitination and subsequent degradation by the $26 \mathrm{~S}$ proteasome. Degradation of IKB $\alpha$ allows NF- $\kappa \mathrm{B}$ to translocate to the nucleus where it can regulate transcription [29,34]. Alternatively, the non-canonical pathway is activated by ligands such as B-cell activating factor family or lymphotoxin beta leading to the NF- $\mathrm{KB}$ inducing kinase (NIK) and IKK alpha (IKK $\alpha$ ) facilitated, proteasome-mediated, conversion of p100 to its active form, p52 [35-37]. This ultimately results in selective activation of the p52/RelB complex and activation of its target gene. There are also other mechanisms of NF- $\mathrm{\kappa B}$ activation including those that involve the calpain family of calcium-dependent proteases [38-40], hypoxia-reoxygenation-induced tyrosine phosphorylation of I $\mathrm{I} B \alpha$ that leads to its dissociation from NF- $\mathrm{B} B$ without degradation [41], ultraviolet irradiation induced phosphorylation of I $\mathrm{K} B \alpha$ via casein kinase II leading to its degradation and NF- $\kappa B$ activation [42], and a pathway referred to as PIR (proteasome inhibitor resistant) that involves degradation of IкB $\alpha$ in a manner independent of proteasomes but dependent on calcium, calmodulin, and L-type calcium channels [4346]. Thus, depending on physiologic and pathologic settings, different NF-кB activation mechanisms could be involved, some sensitive to proteasome inhibitors while others not.

While inducible pathways of NF-kB activation are better characterized, less is known about the mechanisms of constitutive NF- $\kappa B$ activation. In addition to MCL, constitutive NF- $\kappa \mathrm{B}$ activity has also been demonstrated in other malignancies including, adult T-cell leukemia, diffuse large B-cell lymphoma, multiple myeloma, Reed-Sternberg cells of Hodgkin lymphoma, pancreatic adenocarcinoma, prostate adenocarcinoma, squamous cell carcinoma of the head and neck, and breast carcinoma [47-53]. Recent studies examining multiple myeloma samples have demonstrated that $20 \%$ of patient samples harbor mutations or amplifications of genes whose protein products participate in either canonical or noncanonical NF- $\mathrm{KB}$ signaling pathways, leading to constitutive NF- $\kappa \mathrm{B}$ activation $[54,55]$. Among the many different NF- $\kappa \mathrm{B}$ activation mechanisms, the PIR pathway has been found constitutively active in a variety of cell lines analyzed, including the WEHI231 and other murine B-cell lymphoma lines, during in vitro differentiation of a v-Abl transformed pre-B cell line, the MDA-MB 468 human breast cancer cell line, and the RPMI8226 human multiple myeloma cell line [43-46,56-59]. Importantly, the PIR pathway for constitutive NF- $\mathrm{B}$ B activation has been shown to be highly resistant to over 10 different types of proteasome inhibitors analyzed, including bortezomib, but selectively sensitive to inhibition by perillyl alcohol $(\mathrm{POH})$, a monoterpene with anticancer activity which can, among other activities, block L-type calcium channels $[45,46,58,60]$. It is as yet unknown whether MCL harbors PIR constitutive NF- $\kappa \mathrm{B}$ activity. 
Herein, we show that Rec- 1 cells have constitutive PIR NF$\kappa \mathrm{B}$ activation and they are more bortezomib-resistant relative to Jeko- 1 cells which lack PIR activation. Inhibiting PIR NF-KB activity with $\mathrm{POH}$ is synergistic with bortezomib in inducing Rec-1 cell death. Moreover, eight of ten primary MCL samples analyzed demonstrated constitutive NF- $\mathrm{KB}$ activity with high resistance to bortezomib. Overall, we show that bortezomib-resistant constitutive NF- $\mathrm{KB}$ activity is frequently observed in primary MCL samples, suggesting that nonproteasome-dependent mechanisms, including the PIR pathway, may be relevant to MCL biology.

\section{Materials and methods \\ Cell lines, antibodies, and chemicals}

Two well-characterized Epstein-Barr virus-negative human MCL cell lines, Jeko-1 and Rec-1 [61] were cultured in RPMI 1640 (Mediatech Inc, Herndon, VA) supplemented with $10 \%$ fetal bovine serum (HyClone Laboratory, Logan, UT), 1250 U of penicillin G (SigmaAldrich, St. Louis, MO), $0.5 \mathrm{mg}$ of streptomycin sulfate (Sigma), and $0.1 \%$ Basal Medium Eagle amino acid supplement in $37^{\circ} \mathrm{C}$ incubators with $5 \% \mathrm{CO}_{2}$. p65 (C20) and RelB (C19) antibodies were purchased from Santa Cruz Biotechnology (Santa Cruz, CA), p50 (06-886) and p52/ p100 (06-413) antibodies were purchased from Upstate Biotechnologies (Lake Placid, NY), and the cRel (SA-172) antibody was purchased from Biomol (Plymouth Meeting, PA). Bortezomib was commercially obtained from Millenium Pharmaceuticals, Inc. (Cambridge, MA) for experimental purposes. Propiduim iodide (PI) was purchased from Sigma-Aldrich (St. Louis, MO) and Aldrich Chemical Company (Milwaukee, WI) supplied the perillyl alcohol (POH). BAPTA/AM [bis-(o-aminophenoxy)ethane- $N, \quad N, \quad N^{\prime}, \quad N^{\prime}$-tetra-acetic acid tetrakis(acetoxymethyl ester)], EGTA/AM [ethylene glycol tetraacetic acid tetrakis-(acetoxymethyl ester)], W12 [N-(4aminobutyl)-1-naphthalenesulphonamide], and W13 [N(4-aminobutyl)-5-chloro-1-naphthalenesulphonamide] were purchased from Calbiochem (San Diego, CA).

\section{Electrophoretic mobility shift assay (EMSA)}

For MCL cell lines, approximately $1.0 \times 10^{6}$ cells $/ \mathrm{mL}$ were allowed to rest for 2-4 hours in a 5\% $\mathrm{CO}_{2}$ incubator at $37^{\circ} \mathrm{C}$. Cells were then treated with the appropriate chemicals and spun down at 13,000 $\times g$ in a benchtop Eppendorf centrifuge for 10 seconds. Pellets were washed once in $1 \times$ phosphate buffered saline (PBS), spun down again at 13,000 $\times \mathrm{g}$ in a benchtop Eppendorf centrifuge for 10 seconds, and stored at $-70^{\circ} \mathrm{C}$. Cell pellets were lysed in totex buffer (20 mM HEPES [pH 7.9], $350 \mathrm{mM} \mathrm{NaCl}, 20 \%$ glycerol, $1 \% \mathrm{NP}-40,1 \mathrm{mM} \mathrm{MgCl} 2,0.5 \mathrm{mM}$ EDTA, $0.1 \mathrm{mM}$ EGTA, $0.5 \mathrm{mM}$ DTT, $0.5 \mathrm{mM}$ PMSF, $1 \mathrm{ug} / \mathrm{mL}$ aprotinin), spun down at $13,000 \times g$ in an Eppendorf centrifuge for 10 minutes at $4{ }^{\circ} \mathrm{C}$ to remove cell debris, and the superna- tant subjected to the assay as described previously [62], except for the use of a mini-EMSA tailored for the limited protein extracts from the primary MCL samples. Here, 6 $\mu \mathrm{L}$ of reaction was set up and $5 \mu \mathrm{L}$ of each reaction mix was loaded onto $10 \mathrm{~mm} \times 3 \mathrm{~mm} \times 1 \mathrm{~mm}$ wells. The Igк$\kappa \mathrm{B}$ oligonucleotide probe was as described previously [62]. For supershift assays, the indicated antibodies were

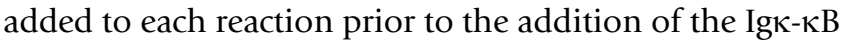
probe. Gels were dried and exposed on Phosphor Screens (Amersham Biosciences, Piscattaway, NJ) followed by quantitation of NF-kB DNA-binding through ImageQuant analysis (GE Healthcare, Piscattaway, NJ). Fold intensity for each lane was normalized to Oct-1 values from the same sample and then to the vehicle treated control values at the indicated time point.

For primary MCL samples, the equivalent of one half of the protein from $5.0 \times 10^{4}$ cells from the Z138 MCL cell line was loaded in each well of the mini-EMSA. In order to correct for differences in amounts of protein between each lane in a gel, fold intensity for each lane was normalized to Oct- 1 values from the same sample and then to the vehicle treated control value. Additionally, one half of total protein from $5.0 \times 10^{4} \mathrm{Z} 138$ cells was run in parallel with every patient sample to serve as an internal standard in order to facilitate comparison of relative constitutive NF- $\kappa \mathrm{B}$ activities between each of the MCL patient samples. To this end, densitometry values of primary MCL samples were additionally normalized to the internal standard Z138 value.

\section{Apoptosis assays}

PI staining was used to examine cell death in non-fixed cells by flow cytometric analysis. $30 \mathrm{ug} / \mathrm{mL}$ of PI was added to the cells 5 minutes prior to data collection on a FACSCalibur flow cytometer (Becton Dickinson Bioscience, San Jose, CA) followed by analysis on Cell Quest software (Becton Dickinson Bioscience) [63].

\section{5 proteasome activity assay}

A live-cell luminogenic substrate based assay of the chymotrypsin-like activity of the $26 \mathrm{~S}$ proteasome was used according to the manufacturer's instructions (Proteasome-Glo Assay with Suc-LLVY-Glo substrate, Promega Corporation, Madson, WI). Luminescence was recorded on a plate-reading luminometer (PerkinElmer, Waltham, MA).

\section{Drug combination evaluation}

The cytotoxic effect of combined bortezomib and POH on MCL cell lines was determined by the combination index (CI) method, based on the median-effect principle derived by Chou and Talalay $[64,65]$, and analyzed by the Calcusyn computer program (Biosoft, Cambridge, UK). Briefly, median-effect analysis is a measure of synergism 
or antagonism where the median-effect equation correlates the drug dose with cytotoxic effect in the equation: $f_{a} /$ $f_{u}=\left(D / D_{m}\right)^{m}$ in which $D$ is the dose of the drug; $D_{m}$ is the median-effect dose signifying the potency, determined from the x-intercept of the median-effect plot; $f_{a}$ is the fraction affected by the dose; $f_{u}$ is the fraction unaffected; and $m$ is an exponent that signifies the sigmoidocity of the dose-effect curve. $\mathrm{CI}$ is then calculated: $\mathrm{CI}=(D)_{1} /\left(D_{x}\right)_{1}+$ $(D)_{2} /\left(D_{x}\right)_{2}$, where $(D)_{1}$ and $(D)_{2}$ are the doses of drug 1 and drug 2 that have $x$ effect when used in combination and $\left(D_{x}\right)_{1}$ and $\left(D_{x}\right)_{2}$ are the doses of drug 1 and drug 2 that have the same $x$ effect when used alone. Synergy is present when the $\mathrm{CI}$ is less than 1.0. The combination is additive when CI equals 1.0, and is antagonistic when greater than 1.0 .

\section{Primary MCL samples}

Twenty samples of fresh bone marrow, peripheral blood, or lymph node (Table 1) were obtained from patients diagnosed with MCL according to World Health Organization criteria [1] either at the time of initial diagnosis or disease recurrence. The specimens were cryopreserved in a solution containing 20\% DMSO in RPMI media with $10 \%$ fetal calf serum after enrichment of mononuclear cells by density gradient separation and stored at $-140^{\circ} \mathrm{C}$. At the time of analysis, specimens were thawed and anti-CD19 magnetic microbeads were used to positively select cells through the MACS cell sorting system following the manufacturer's protocol (Miltenyi Biotec, Auburn, CA). From the 20 cases, 10 that had greater than $60 \%$ lymphocytes that co-expressed CD5 with CD19 and had greater than $5.0 \times 10^{5}$ cells for EMSA analysis were included. In these 10 cases, the mean percentage of lymphocytes demonstrating the MCL phenotype with combined expression of CD5 and CD19 was $78 \%$ (range $62 \%$ to $96 \%$ ) as analyzed on a FACSCalibur flow cytometer (Becton Dickinson, Franklin Lakes, NJ) with anti-CD5-PE and anti-CD19PECy5 antibodies (BD Biosciences, San Jose, CA) (Table 1 ). The primary cells were cultured in media identical to that used for the MCL cell lines.

\section{Results \\ Constitutive NF- $K B$ activation in two MCL cell lines is associated with distinct NF- $K B$ heterodimers and mechanisms}

Constitutive activation of NF- $\mathrm{BB}$ has been implicated as a critical modulator of malignant cell growth and survival in a number of human malignancies including MCL [25,47-53]. To avoid complications arising from the latent membrane protein 1 of EBV, which has been shown to activate NF-kB [66], we first investigated constitutive NF$\kappa \mathrm{B}$ complexes in the EBV-negative MCL cell lines, Jeko-1 and Rec-1, using EMSA. Both cell lines demonstrated constitutive NF- $\mathrm{KB}$ activation with Rec-1 cells having relatively more activity than Jeko-1 cells (Figure 1A). Supershift analysis showed that Jeko- 1 and Rec-1 cells contain both p50/p65 and p50/cRel heterodimers, with Rec- 1 having relatively more p50/cRel (Figure 1B). NF- $\kappa B$ p50/p65 and p50/cRel heterodimers can be activated via both canonical, PIR, and other pathways [34,44,45], suggesting that distinct mechanisms mediating constitutive NF- $\kappa B$ activation may exist in these MCL cell lines.

We next investigated whether a proteasome inhibitor resistant activation pathway was involved in maintaining constitutive NF- $\mathrm{\kappa B}$ activity in Jeko- 1 and Rec-1 cells. To evaluate the efficacy of inhibition of the chymotryptic-like proteasomal activity in these cells by bortezomib, a livecell luminogenic substrate based assay was used (see Materials and Methods). Both cell lines showed marked inhibition of proteasomal activity following treatment with bortezomib. Exposure of these cells to $20 \mathrm{nM}$ of bortezomib for four hours decreased proteasome activity to less than $20 \%$ of vehicle treated controls (Figure 2A).

Next, we evaluated the effect of proteasome inhibition on constitutive NF- $\mathrm{KB}$ activity. NF- $\mathrm{KB}$ activity was decreased in Jeko- 1 cells but not in Rec- 1 cells after 4 hour treatment with either $20 \mathrm{nM}$ bortezomib (Figure 2B) or $100 \mathrm{nM}$ of bortezomib (data not shown). The bortezomib-resistance of constitutive p50/p65 and p50/c-Rel activity in Rec-1

Table I: Characteristics of MCL patient samples.

\begin{tabular}{|c|c|c|c|c|c|c|}
\hline Patient no. & Age (years) & Gender & Source & Disease status & Morphologic variant & Tumor cells (\%)! \\
\hline 1 & 81 & $\mathrm{~F}$ & Bone marrow & Primary & Blastic & 61.6 \\
\hline 2 & 58 & $\mathrm{~F}$ & Bone marrow & Recurrence & Classic & 95.6 \\
\hline 3 & 77 & $\mathrm{~F}$ & Peripheral blood & Primary & Blastic & 74.8 \\
\hline 4 & 75 & $\mathrm{~F}$ & Bone marrow & Primary & Blastic & 71.1 \\
\hline 5 & 56 & $\mathrm{~F}$ & Lymph node & Primary & Classic & 83.0 \\
\hline 6 & 53 & $\mathrm{~F}$ & Lymph node & Recurrence & Classic & 88.6 \\
\hline 7 & 49 & $M$ & Peripheral blood & Primary & Classic & 96.1 \\
\hline 8 & 57 & $\mathrm{~F}$ & Bone marrow & Primary & Classic & 83.6 \\
\hline 9 & 62 & $M$ & Bone marrow & Recurrence & Classic & 76.8 \\
\hline 10 & 67 & $M$ & Bone marrow & Primary & Classic & 69.7 \\
\hline
\end{tabular}

I Percentage of cells co-expressing CD5 and CDI9 after CDI9 positive cell selection. 
A.

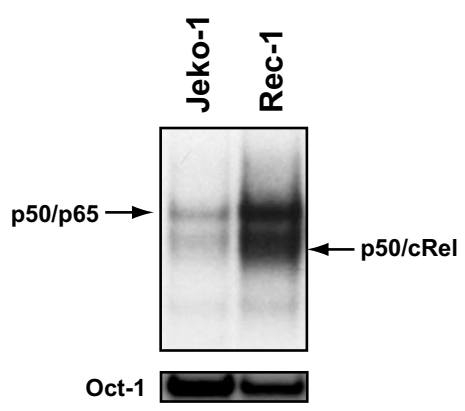

B.

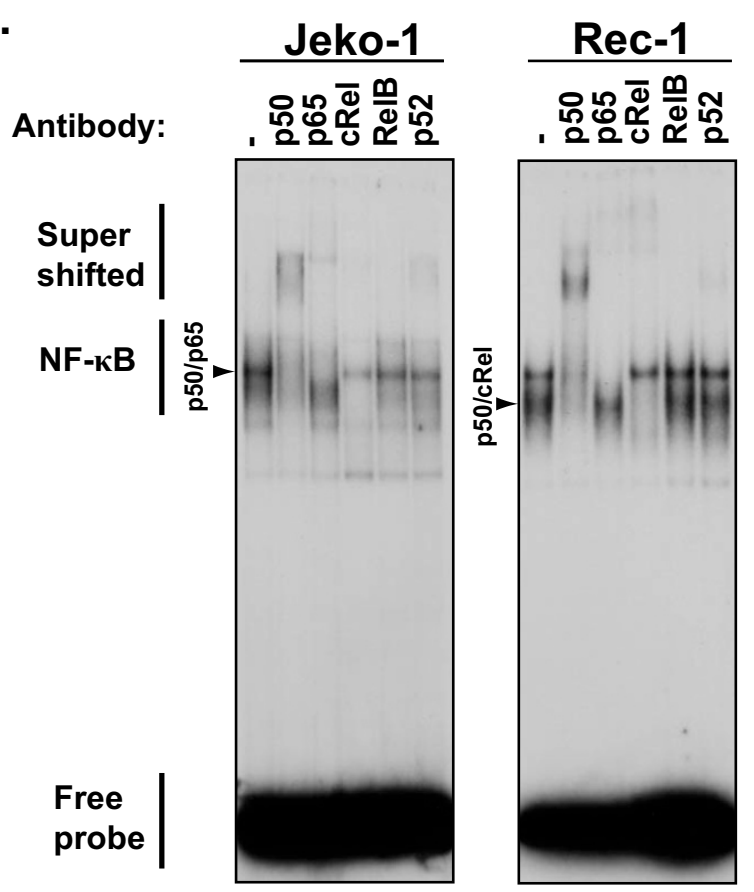

\section{Figure I}

Constitutive NF- $\kappa$ B activation in MCL cell lines. (A) Electrophoretic mobility shift assay (EMSA) of whole cell extracts from $1.0 \times 10^{6}$ cells of EBV-negative MCL cell lines probed with ${ }^{32} \mathrm{P}$-radiolabeled oligonucleotide containing the consensus NF$\kappa \mathrm{B}$ binding sequence. Oct-I binding is shown as a loading control. Assignment of the NF- $\kappa \mathrm{B}$ complexes are based on supershift analysis shown in (B). (B) Supershift EMSA of whole cell extracts from MCL cell lines.

cells could be due to the involvement of the PIR pathway. To determine if this is the case, we treated Rec- 1 cells with agents known to block the PIR pathway, including calcium chelators (BAPTA/AM and EGTA/AM), calmodulin inhibitors (W12 and W13) and the anticancer agent, $\mathrm{POH}$ [43-46]. As shown in Figure 2C and 3C, these agents effectively blocked constitutive NF-kB activity in this cell line, thereby suggesting the involvement of the PIR pathway.
Synergism of POH with bortezomib in a MCL cell line harboring bortezomib-resistant constitutive NF- $\kappa$ B activity Because NF- $\kappa \mathrm{B}$ has been shown to mediate cellular growth and survival in MCL [25], we evaluated whether cells possessing bortezomib-resistant constitutive NF- $\mathrm{B}$ activity would in fact demonstrate a survival advantage in the face of bortezomib treatment. PI staining was used to assess the cytotoxic effect of 24 hour treatment with $20 \mathrm{nM}$ bortezomib on the MCL cell lines. This method enables enumeration of both apoptotic and necrotic non-fixed cells by flow cytometric analysis (Figure 3A) [46,63]. Jeko-1 
A.

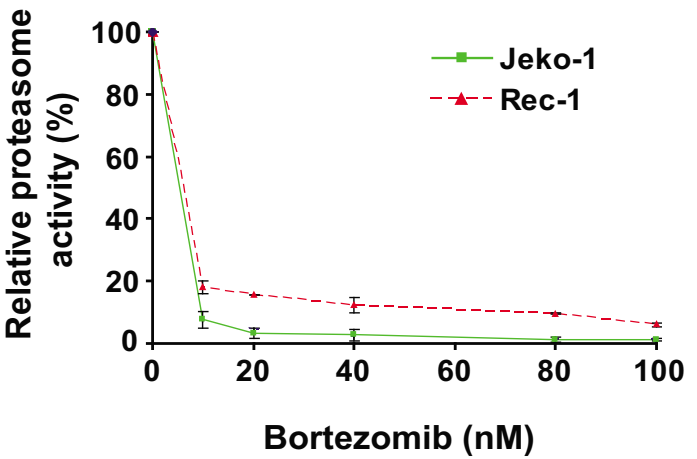

B.

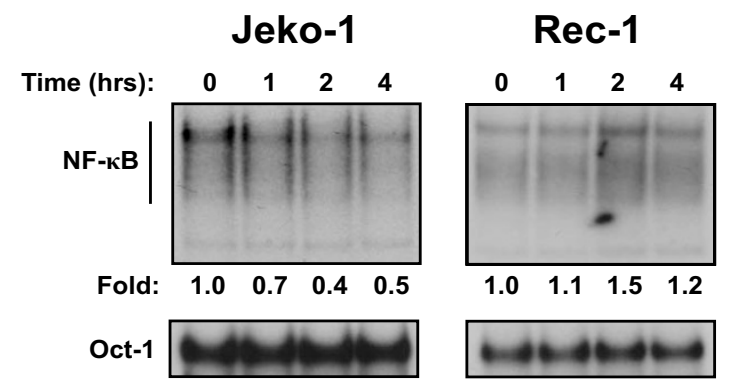

C.

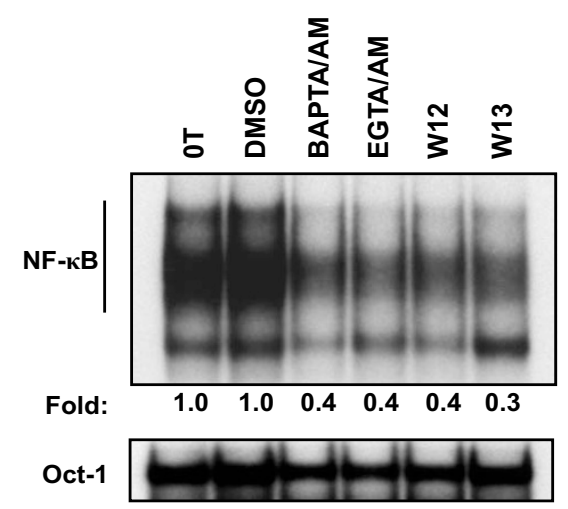

Figure 2

Bortezomib-resistant constitutive NF- $\kappa$ B activity in Rec-I cells. (A) Chymotrypsin-like activity of the $26 \mathrm{~S}$ proteasome in cell lines after exposure to increasing doses of bortezomib for 4 hours was assessed by luminescence generated by substrate cleavage (Proteasome-Glo Assay, Promega Corporation, Madison, WI). Results (mean + ISD from triplicate wells) are shown as a percent of luminescence relative to vehicle treated controls. (B) EMSAs of $\mathrm{MCL}$ cell lines treated with $20 \mathrm{nM}$ bortezomib for I to 4 hours probed with $32 \mathrm{P}$-radiolabeled oligonucleotide containing either the consensus NF- $\mathrm{KB}$ or Oct-I binding sequence. Fold intensity was calculated by ImageQuant analysis of Phosphor Screens normalized to Oct-I values from the same sample and then to the vehicle treated control values at the indicated time point. Gels shown are representative of one of three independent experiments. (C) EMSA of Rec-I cells at time zero (OT) and treated with $0.1 \%$ DMSO (DMSO) for 3 hours, the calcium chelators BAPTA/AM $(60 \mu M)$ and EGTA/AM $(60 \mu M)$ for 3 hours, or the calmodulin inhibitors WI2 $(40 \mu \mathrm{M})$ and WI $3(10 \mu \mathrm{M})$ for 3 hours. Fold activity refers to NF-kB binding normalized to Oct-I binding in each condition. Gel shown is representative of 3 independent experiments. 
A.

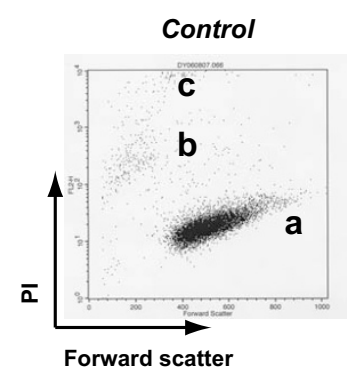

B.

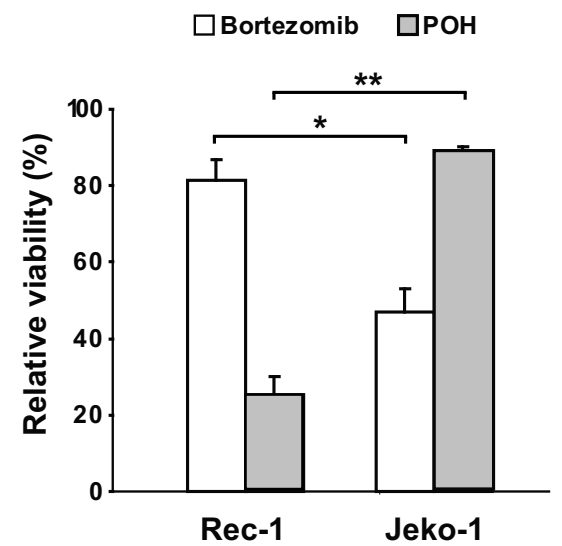

Bortezomib 20nM

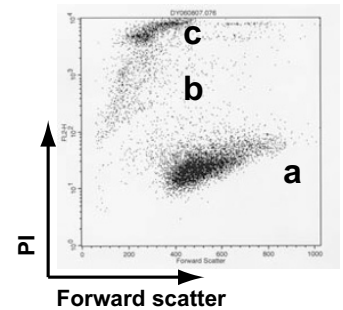

Forward scatter

C.

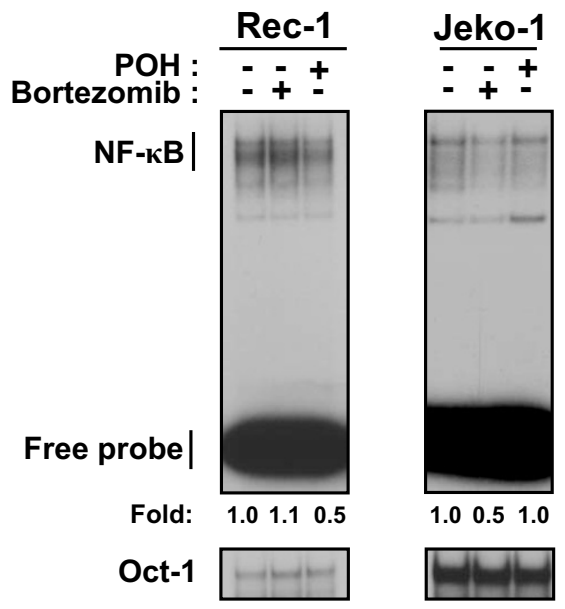

Figure 3

Cytotoxic effect of bortezomib and POH on MCL cell lines. (A) Assessment of viability by staining non-fixed Rec-I cells with $\mathrm{PI}(30 \mu \mathrm{g} / \mathrm{mL})$ followed by flow cytometric analysis showing populations of (a) live cells, (b) necrotic cells, and (c) apoptotic cells. (B) Viability of Rec-I and Jeko-I cells treated with either $20 \mathrm{nM}$ bortezomib or $0.3 \mathrm{mM}$ POH for 24 hours relative to controls exposed only to vehicle shown as mean \pm ISD from triplicate wells. The unpaired $t$-test between viability of Jeko-I and Rec-I cells treated with bortezomib $* p=0.002$ or $\mathrm{POH} * *_{p}=0.000 \mathrm{I}$ were both statistically significant $(p<0.0 \mathrm{I})$. (C) EMSAs of whole cell extracts from I.0 × $10^{6}$ cells treated with $20 \mathrm{nM}$ bortezomib or their respective median-effect dose of $\mathrm{POH}$ for 4 hours probed with ${ }^{32} \mathrm{P}$-radiolabeled oligonucleotide containing either the consensus NF- $\mathrm{KB}$ or Oct-I binding sequence. Fold activity refers to NF- $\kappa B$ binding normalized to Oct-I binding in each condition.

cells were sensitive to bortezomib induced cytotoxicity and Rec- 1 cells were significantly less so with $47 \pm 6.2 \%$ and $82 \pm 5.1 \%$ viability respectively, relative to vehicle treated controls (Figure 3B).

To determine if inhibition of the PIR NF-kB activity with $\mathrm{POH}$ would induce bortezomib sensitization, we next evaluated synergy between bortezomib and $\mathrm{POH}$ in the Rec-1 cells. We also treated Jeko- 1 cells as a negative control since constitutive NF- $\mathrm{KB}$ activity in this cell line demonstrated high sensitivity to bortezomib but not to $\mathrm{POH}$ (Figure 3C). To accurately compare the effect of $\mathrm{POH}$ on NF- $\kappa B$ activity in Jeko- 1 and Rec-1 cells, we first determined the potency of POH in each cell line by assessing cytotoxicity through PI staining followed by flow cytometric quantification and calculation of the median-effect dose $\left(D_{m}\right)$ for each cell line (see methods). We found that
POH was more potent in Rec- $1\left(D_{m}=0.32 \mathrm{mM}\right)$ than Jeko-1 $\left(\mathrm{D}_{m}=0.67 \mathrm{mM}\right)$ cells (Figure $\left.4 \mathrm{~A}\right)$. These anti-MCL doses are similar in range to those seen against other cancer types [67-70]. When treated with their respective $\mathrm{D}_{m}$ of POH for 4 hours, NF-kB activity was reduced in Rec- 1 but not Jeko-1 cells (Figure 3C). When Rec-1 cells were treated with a fixed ratio of bortezomib and $\mathrm{POH}$, analysis for synergy by the method of Chou-Talalay showed combination indices (CI) of 0.83 and 0.74 at ED75 and ED90, respectively (Figure $4 \mathrm{~B}$ ). These $\mathrm{CI}$ values are $<1.0$, indicating synergistic toxicity with $\mathrm{POH}$ and bortezomib. In contrast, parallel synergy experiments in Jeko-1 cells demonstrated CIs of 1.13 and 1.03 at ED75 and ED90, respectively (Figure 4B), suggesting not only a lack of synergy, but even a modest antagonism. These findings show that inhibition of constitutive PIR NF- $\mathrm{BB}$ activity in Rec-1 cells by $\mathrm{POH}$ induces synergistic toxicity with bortezomib. 
A.
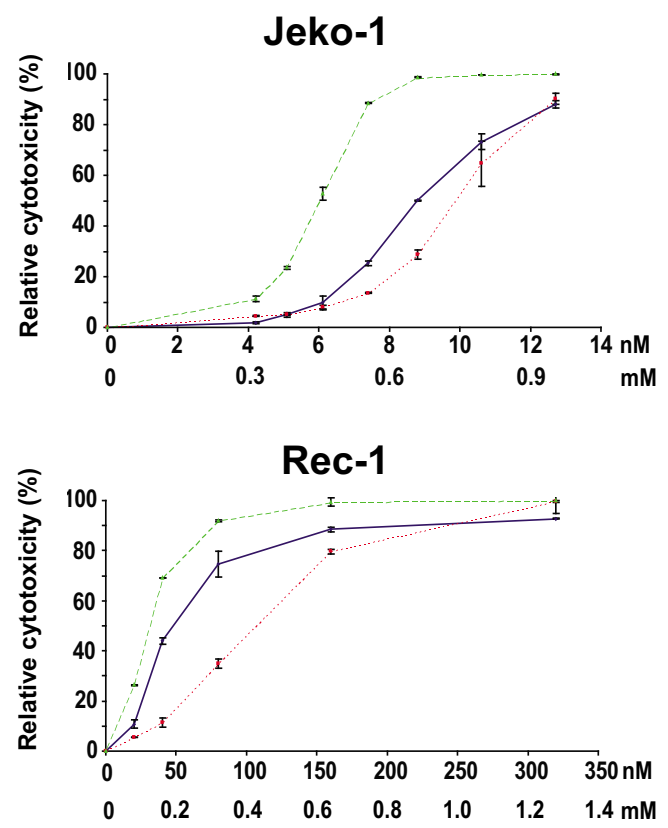

B.
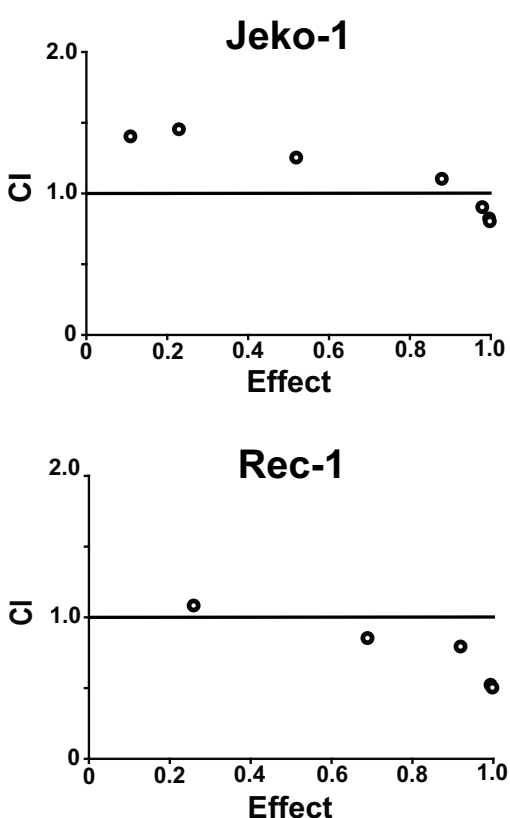

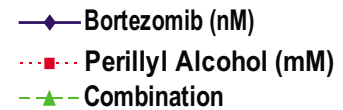

\section{Figure 4}

POH synergizes with bortezomib in inducing cytotoxicity in Rec-I, but not Jeko-I cells. (A) Viability assessed by PI staining with flow cytometric quantitation relative to controls exposed only to vehicle at various doses of bortezomib, $\mathrm{POH}$, or combination of both for 24 hours. Results expressed as mean \pm ISD of triplicate wells. (B) Combination index (CI) plots generated by the computer software CalcuSyn (Biosoft, Cambridge, UK) according to the Chou-Talalay equation ("Materials and Methods") from cytotoxicity data shown in (A). Effect is equivalent to cytotoxicity where effect of I.0 = $100 \%$ relative cytotoxicity. Synergy is present when $\mathrm{Cl}<\mathrm{I}$.0. The combination is additive when $\mathrm{Cl}=1.0$, and antagonistic when $\mathrm{Cl}>\mathrm{I} .0$.

This synergy is not seen in Jeko-1 cells that harbor constitutive NF- $\kappa \mathrm{B}$ activity utilizing the proteasome-dependent canonical pathway.

\section{Bortezomib-resistant constitutive NF- $\kappa B$ activity is frequently observed in primary MCL samples}

Since the number of primary MCL cells in patient-derived samples is very limited in general, we next developed a scaled down version of the traditional EMSA assay ("miniEMSA") (see methods). In order to validate the precision of this assay, assessment of NF-KB band intensities of 5 replicate samples calculated by ImageQuant analysis of Phosphor Screens exposed to the dried mini-EMSAs loaded with half the protein extracts from 2.5 and $5.0 \times$ $10^{4}$ cells from the Z138 MCL cell line was performed. The other half samples were used for the loading control Oct1 binding. The coefficient of variation of this assay for 5.0 $\times 10^{4} \mathrm{Z} 138$ cells was of $5.9 \%$ (Figure $5 \mathrm{~A}$ and $5 \mathrm{~B}$ ). While cell numbers greater than $5.0 \times 10^{4}$ produced reproducible results, when cell numbers were reduced below this number, the reproducibility suffered greatly. Thus, we used $5.0 \times 10^{4} \mathrm{Z} 138$ cell equivalents as the target amount of protein from patient samples to load in each gel. We also ran Z138 cell samples as a standard in each EMSA so that we could compare results between primary samples run on different days in spite of day to day variances of the

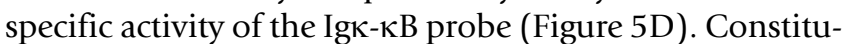
tive NF- $\kappa B$ activity was present in all primary samples and ranged in intensity from 0.16 to 3.45 fold of the Z138 standard cells (Figure 5E).

Next, we investigated the sensitivity of constitutive NF- $\kappa B$ activity in primary MCL samples to treatment with $20 \mathrm{nM}$ or $100 \mathrm{nM}$ of bortezomib for four hours. The degree of 
A.

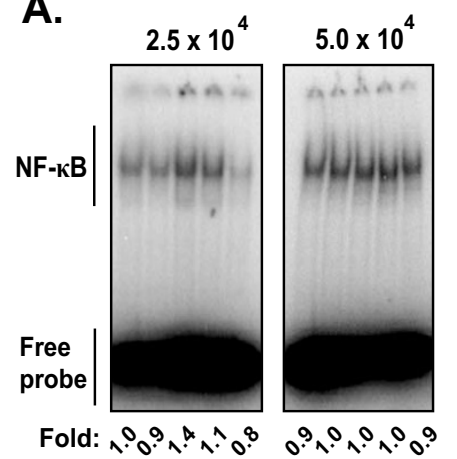

B.

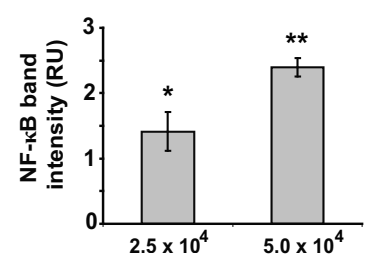

C.

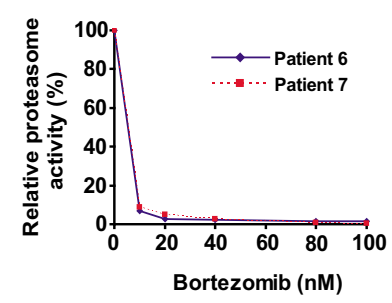

D.

Patient $2 \quad$ Patient 6

Patient 8

Bortezomib (nM):

$020100 \mathrm{Z}$ $020100 \mathrm{Z}$ 020100 Z \begin{tabular}{|l|l|l|} 
NF-kB & \\
Free probe & \\
\hline
\end{tabular}

Fold :

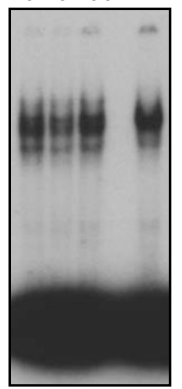

Oct-1 $190 . x^{2}$

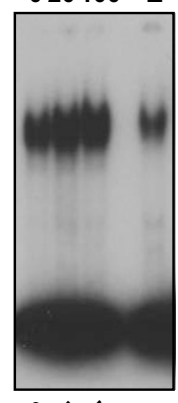

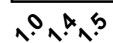
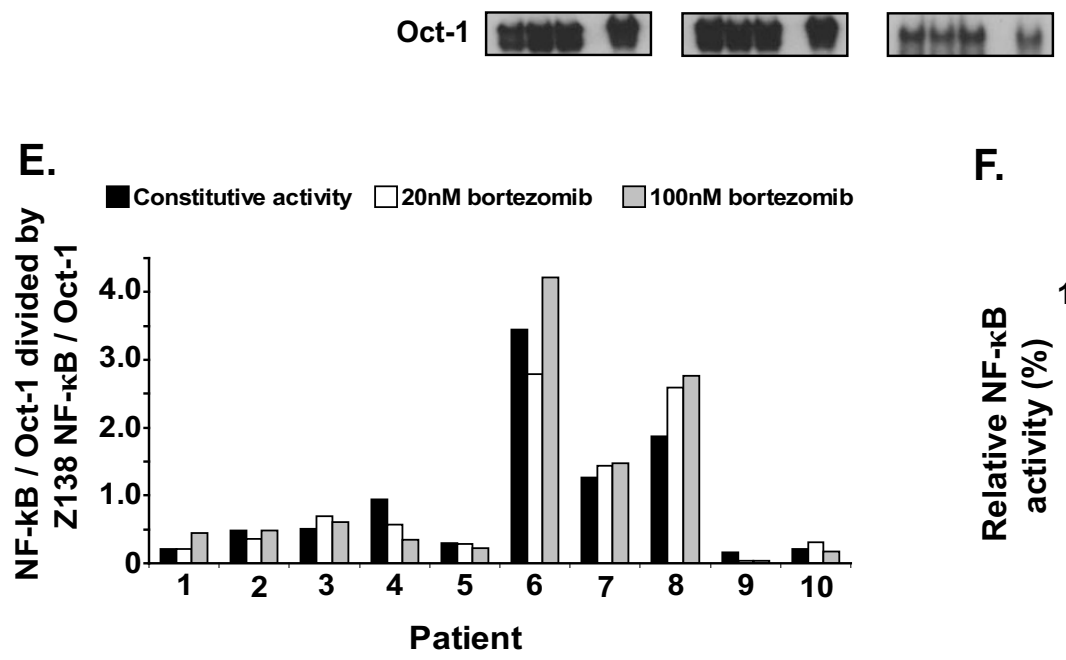

F.

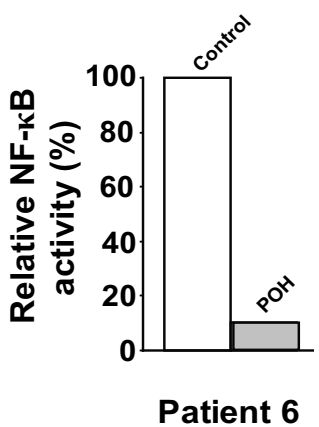

\section{Figure 5}

Bortezomib-resistant constitutive NF- $K B$ activity in MCL patient samples. (A) Mini-EMSA performed on one half of the protein extracts from $2.5 \times 10^{4}$ and $5.0 \times 10^{4} \mathrm{Z} 138$ cells probed with ${ }^{32} \mathrm{P}$-radiolabeled oligonucleotide containing the consensus NF- $\mathrm{KB}$ sequence. (B) Mean \pm ISD of densitometric values in relative units $(R U)$ from ImageQuant analysis of Phosphor Screens exposed to mini-EMSA from (A). ${ }^{*}$ Coefficient of variation $(C V)=20.9 \%$ $*_{*} \mathrm{CV}=5.9 \%$ (C) Chymotrypsin-like activity of the $26 \mathrm{~S}$ proteasome in 2 patient samples after exposure to increasing doses of bortezomib for 4 hours as assessed by luminescence generated by substrate cleavage (Proteasome-Glo Assay, Promega Corporation, Madison, WI). Results are shown as percent of luminescence relative to a vehicle treated control in a single experiment. (D) Mini-EMSA of anti-CDI 9 magnetic microbead selected cells from MCL patient samples treated with $20 \mathrm{nM}$ and $100 \mathrm{nM}$ of bortezomib for 4 hours. Z represents a standard composed of $5.0 \times 10^{4} \mathrm{ZI} 38$ cells run with each patient sample as an internal control. The protein extract from this standard was halved, with each half run alongside corresponding halved patient samples, where one half was probed with oligonucleotide containing the NF- $\kappa B$ consensus binding sequence and the other half probed with oligonucleotide containing the Oct-I consensus binding sequence. (E) NF-KB DNA-binding of MCL patient samples corrected for Oct-I intensity then normalized to their respective vehicle treated control and finally normalized to ZI38 internal control for $M C L$ patient samples processed and analyzed as described in (D). (F) NF-KB DNA-binding of MCL patient 6 after treatment with $1.0 \mathrm{mM} \mathrm{POH}$ for 4 hours relative to vehicle treated control, corrected for Oct-I intensity. 
proteasome inhibition achieved at these dosages in two representative patients (patient 6 and patient 7 ) was comparable to that seen in the MCL cell lines tested by the same assay (Figure 5C). Relative to vehicle treated controls, only two patients (patient 4 and patient 9) demonstrated a $50 \%$ or greater decrease of NF- $\kappa B$ DNA-binding after treatment by either dose of bortezomib (Figure 5E). Constitutive NF- $\kappa B$ activity in patients 2 and 6 showed a very modest inhibition with $20 \mathrm{nM}$ bortezomib, but interestingly not at the $100 \mathrm{nM}$ dose. The others did not show any overt inhibition of NF-kB activity. Some patient samples $(3,7$ and 8$)$ showed modest increases in constitutive NF- $\mathrm{B}$ activity after treatment of cells with bortezomib. Significantly, POH treatment of cells from patient 6 , which had the most robust degree of constitutive activity, resulted in marked inhibition of NF- $\mathrm{KB}$ activity (Figure $5 \mathrm{~F}$ ). These results reveal that constitutive NF- $\mathrm{B}$ activity present in a considerable fraction of primary MCL cases is refractory to inhibition by high dose bortezomib treatment. Moreover, this resistance is at least in part due to the involvement of the PIR pathway in MCL samples.

\section{Discussion}

Under normal circumstances, the NF-kB signaling pathway is tightly controlled and plays important roles in lymphocyte development and the immune response; however, dysregulation of this pathway can lead to its constitutive activation in cancer cells. Although the proteasome inhibitor bortezomib can target the constitutive NF- $\kappa$ B activity maintained by both canonical and noncanonical pathways, proteasome inhibitor resistant mechanisms of NF- $\mathrm{KB}$ activation have been identified and one of them in particular, the PIR pathway, is constitutively activated in several cancer cell lines [43-46,56-58]. The PIR pathway may provide cancer cells a mechanism of maintaining constitutive NF- $\mathrm{BB}$ activation in the face of proteasome inhibition and confer a degree of relative resistance to proteasome inhibitor induced cytotoxicity. In turn, assessing the prevalence of bortezomib-resistant constitutive NF- $\kappa \mathrm{B}$ activity in MCL patient samples illuminates whether proteasome inhibition can efficiently abrogate constitutive NF-kB activity MCL patients. Here, we

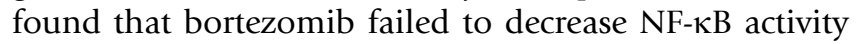
by more that $50 \%$ in eight of ten primary patient samples, despite treatment with doses that elicited greater than $80 \%$ proteasome inhibition, which is the clinical target with this drug. These results demonstrate a surprising finding that constitutive NF- $\mathrm{KB}$ activity in primary MCL cells is often resistant to bortezomib exposure, at least in vitro.

We evaluated the EBV-negative Jeko- 1 and Rec- 1 cell lines to eliminate the effect of NF- $\mathrm{KB}$ activation by latent membrane protein 1 , which would work via the canonical pathway [66]. Dosages of bortezomib chosen were reflec- tive of pharmacokinetic studies where patients on standard bortezomib dosing regimens of $1.0 \mathrm{mg} / \mathrm{m}^{2}$ had estimated peak plasma concentrations of approximately $200 \mathrm{nM}$ that rapidly decreased and plateaued at approximately $5 \mathrm{nM}$ in less than 5 hours, and concordantly, peak inhibition of proteasome activity in whole blood lysates reached approximately $75 \%$, falling off to approximately $35 \%$ after 24 hours [71-73]. As such, in the MCL cell lines, we used a $20 \mathrm{nM}$ dose of bortezomib for 4 hours that produced at least $80 \%$ proteasome inhibition to reflect maximal proteasome inhibition achievable with a reasonably attainable plasma bortezomib concentration. In primary MCL samples, because we could not assess the effect of bortezomib on proteasome activity in each case due to limitation of MCL cell number, we treated samples with both $20 \mathrm{nM}$ and $100 \mathrm{nM}$ bortezomib when determining its effect on NF- $\kappa B$ activation to ensure that sufficient proteasome inhibition was attained.

Constitutive NF- $\kappa \mathrm{B}$ activity was present in both Jeko-1 and Rec-1 cells. Jeko-1 cells appeared to constitutively activate NF- $\kappa \mathrm{B}$ through the canonical pathway as evidenced by the presence of largely p50/p65 heterodimers and inhibition of constitutive NF- $\mathrm{KB}$ activity by bortezomib. In contrast, Rec-1 cells appeared to activate NF- $\mathrm{BB}$ through the PIR pathway, where despite proteasome inhibition by bortezomib, DNA-binding by largely p50/cRel heterodimers was not inhibited; similar to our observations in the WEHI231 murine B-cell lymphoma cell line which displays a high-level of proteasome inhibitor resistant constitutive NF- $\kappa B$ activity [43-46,56-58]. This activity was nevertheless sensitive to inhibition by calcium chelators, calmodulin inhibitors, and $\mathrm{POH}$, agents that block the PIR pathway but do not generally block canonical or non-canonical pathways.

$\mathrm{POH}$ is a monoterpene derived from plant essential oils that has been shown to have significant antitumor activity against multiple cancer models. [60,67-70] Its mechanism of action includes inhibition of G-protein prenylation $[74,75]$ and alterations in cell cycle genes with decreased cyclin D1 $[76,77]$. Of interest, $\mathrm{POH}$ has also been shown to inhibit the L-type calcium channels important for the maintenance of PIR constitutive NF- $\kappa B$ activity in both WEHI231 lymphoma cells and MDA-MB-468 breast cancer cells [46]. Indeed, in Rec-1 cells, $\mathrm{POH}$ treatment conferred a marked decrease in constitutive NF- $\mathrm{KB}$ activity and correspondingly induced cytotoxicity. In contrast, in Jeko- 1 cells that harbor constitutive NF-кB activation maintained by the canonical pathway, $\mathrm{POH}$ did not decreased NF- $\mathrm{\kappa B}$ activity and were more resistant to $\mathrm{POH}$ relative to Rec-1 cells. Moreover, $\mathrm{POH}$ synergistically caused toxicity in Rec-1 cells, but not in Jeko-1 cells. These results demonstrated a parallelism between bortezomib versus POH sensitivity to canonical versus PIR constitu- 
tive NF- $\kappa \mathrm{B}$ activation. In MCL cells that harbor constitutive PIR NF- $\kappa$ B activity, $\mathrm{POH}$ can synergize with bortezomib to cause cell death.

It is clearly simplistic to view NF- $\kappa \mathrm{B}$ as the sole independent modulator of MCL or other cancer cell death pheno-

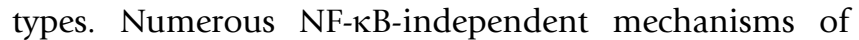
bortezomib-induced apoptosis have been demonstrated in multiple myeloma, lung cancer cells, and squamous cell carcinomas. These include the induction of p53, mouse double minute 2, p21, and p27; phosphorylation of c-Jun NH(2)-terminal kinase and c-Jun; enhanced AP-1 DNA-binding; and induction of the unfolded protein response via accumulation of unfolded or misfolded proteins in the endoplasmic reticulum [78-82]. Furthermore, it has been shown in MCL that a major mode of cell death induction by bortezomib is through generation of ROS and Noxa induction that results in activation of the mitochondrial apoptotic pathway [27]. It is nevertheless also well established that NF- $\mathrm{B}$ can confer additional resistance to MCL cells, although it may not be the major decisive factor in controlling the overall sensitivity to bortezomib. Since the patient samples analyzed herein did not come from those who have been treated with bortezomib and the sample size was relatively small, the correlation between the presence of proteasome inhibitor resistant constitutive NF- $\kappa \mathrm{B}$ activity in MCL samples and bortezomib response in patients could not be assessed. Nevertheless, our data demonstrating synergy between bortezomib and $\mathrm{POH}$ (Figure $4 \mathrm{~A}$ and $4 \mathrm{~B}$ ) suggest the possibility that targeting the PIR pathway of constitutive NF$\kappa \mathrm{B}$ activity with $\mathrm{POH}$ (or other anti-PIR agents) could increase the sensitivity of MCL cells in vivo. This is particularly relevant, since of the 10 evaluable MCL patient cases, all demonstrated constitutive NF- $\kappa \mathrm{B}$ activation and only 2 cases showed greater than a $50 \%$ inhibition of NF$\kappa \mathrm{B}$ activity after exposure to bortezomib.

\section{Conclusion}

This study demonstrates that constitutive NF- $\kappa$ B activity is not only present in MCL patient samples, but this activity is largely resistant to proteasome inhibition by bortezomib in vitro. Additionally, by using Rec-1 cells as a model of bortezomib-resistant constitutive NF- $\kappa \mathrm{B}$ activity, we showed that blocking this activity with $\mathrm{POH}$ was synergistic with bortezomib in inducing cytotoxicity. Thus, our data suggests that the full therapeutic potential of blocking constitutive NF- $\kappa \mathrm{B}$ activity as a treatment strategy for MCL has yet to be fully realized and supports efforts invested towards the discovery and development of compounds capable of inhibiting bortezomib-resistant constitutive NF- $\kappa \mathrm{B}$ activity with potency and specificity superior to $\mathrm{POH}$.

\section{Declaration of competing interests}

The authors declare that they have no competing interests.

\section{Authors' contributions}

DTY contributed to the design of the study, development of the assay system for patient samples, performance of the research, analysis and interpretation of the data, and the writing of the paper. KHY. and BSK contributed to the design of the study, acquisition of patient samples, and critical review of the manuscript. SMarkovina contributed to the initial acquisition of patient samples, development of the assay system for patient samples, and critical review of the manuscript. SMiyamoto contributed to the conceptualization and design of the study, analysis and interpretation of the data, and the writing of the paper. All authors approved the final version of the manuscript.

\section{Acknowledgements}

We thank C. Berchtold, and B. Seufzer for their helpful discussion, insightful suggestions, and technical assistance in the early phase of this work. We acknowledge N. Callander, M. Juckett, C. Leith, W. Longo, T. McFarland, D. Mosher, D. Norback, E. Ranheim, and E. Williams for their clinical and diagnostic expertise regarding the patient samples. We are indebted to $Z$. Estrov for his generous gift of the ZI $38 \mathrm{MCL}$ cell line.

This work was funded in part by NIH grant T32 CA0096 I 4 Physician Scientist Training in Cancer Medicine (D.T.Y.), The Lymphoma Research Foundation (K.H.Y., B.S.K., and S. Miyamoto) and NIH grant R0I-CA08I06 (S. Miyamoto). The funding agencies had no direct role in study design; data collection, analysis, or interpretation; writing of the manuscript; or decision to submit the manuscript for publication.

\section{References}

I. Swerdlow SH, Nathwani BN, Berger F, Piris MA, Isaacson PG, Harris NL, Muller-Hermelink HK: Mantle cell lymphoma. In World Health Organization Classification of Tumours Edited by: Jaffe V, Harris ES, Stein NL. H. Lyon: IARC Press; 200I:160-170.

2. Bosch F, Lopez-Guillermo A, Campo E, Ribera JM, Conde E, Piris MA, Vallespi T, Woessner S, Montserrat E: Mantle cell lymphoma: Presenting features, response to therapy, and prognostic factors. Cancer 1998, 82:567-75.

3. Argatoff LH, Connors JM, Klasa RJ, Horsman DE, Gascoyne RD: Mantle cell lymphoma: A clinicopathologic study of 80 cases. Blood 1997, 89:2067-78.

4. Williams ME, Densmore Jj: Biology and therapy of mantle cell lymphoma. Curr Opin Oncol 2005, 1 7:425-31.

5. Jemal A, Siegel R, Ward E, Murray T, Xu J, Thun MJ: Cancer statistics, 2007. CA Cancer J Clin 2007, 57:43-66.

6. The Non-Hodgkin's Lymphoma Classification Project: A clinical evaluation of the international lymphoma study group classification of non-hodgkin's lymphoma. Blood 1997, 89:3909-3918.

7. Dreyling M, Forstpointner R, Gramatzki M, Bock H, Hanel A, Seymour JF, Planker M, Duhrsen U, Wilms K, Unterhalt M, Hiddemann $W$ : Rituximab maintenance improves progression-free and overall survival rates after combined immun-chemotherapy (R-FCM) in patients with relapsed follicular and mantle cell lymphoma: Final results of a prospective randomized trial of the german low grade lymphoma study group (GLGLSG). J Clin Oncol 2006, 24:422s.

8. Dreyling M, Lenz G, Hoster E, Van Hoof A, Gisselbrecht C, Schmits R, Metzner B, Truemper L, Reiser M, Steinhauer H, Boiron JM, Boogaerts MA, Aldaoud A, Silingardi V, Kluin-Nelemans HC, Hasford J, Parwaresch R, Unterhalt M, Hiddemann W: Early consolidation by myeloablative radiochemotherapy followed by autologous stem cell transplantation in first remission significantly pro- 
longs progression-free survival in mantle-cell lymphoma: Results of a prospective randomized trial of the european MCL network. Blood 2005, 105:2677-2684.

9. Kahl BS, Longo WL, Eickhoff JC, Zehnder J, Jones C, Blank J, McFarland T, Bottner W, Rezazedeh H, Werndli J, Bailey HH, Wisconsin Oncology Network: Maintenance rituximab following induction chemoimmunotherapy may prolong progression-free survival in mantle cell lymphoma: A pilot study from the wisconsin oncology network. Ann Oncol 2006, 17:14|8-1423.

10. Romaguera JE, Fayad L, Rodriguez MA, Broglio KR, Hagemeister FB, Pro B, McLaughlin P, Younes A, Samaniego F, Goy A, Sarris AH, Dang $\mathrm{NH}$, Wang M, V B, Medeiros LJ, Katz RL, Gagneja H, Samuels BI, Smith TL, Cabanillas FF: High rate of durable remissions after treatment of newly diagnosed aggressive mantle-cell lymphoma with rituximab plus hyper-CVAD alternating with rituximab plus high-dose methotrexate and cytarabine. J Clin Oncol 2005, 23:7013-23.

II. Lenz G, Dreyling M, Hoster E, Wormann B, Duhrsen U, Metzner B, Eimermacher H, Neubauer A, Wandt H, Steinhauer H, Martin S, Heidemann E, Aldaoud A, Parwaresch R, Hasford J, Unterhalt M, Hiddemann W: Immunochemotherapy with rituximab and cyclophosphamide, doxorubicin, vincristine, and prednisone significantly improves response and time to treatment failure, but not long-term outcome in patients with previously untreated mantle cell lymphoma: Results of a prospective randomized trial of the german low grade lymphoma study group (GLSG). J Clin Oncol 2005, 23: 1984-92.

12. Nickenig C, Dreyling M, Hoster E, Pfreundschuh M, Trumper L, Reiser M, Wandt H, Lengfelder E, Unterhalt M, Hiddemann W: Combined cyclophosphamide, vincristine, doxorubicin, and prednisone (CHOP) improves response rates but not survival and has lower hematologic toxicity compared with combined mitoxantrone, chlorambucil, and prednisone (MCP) in follicular and mantle cell lymphomas: Results of a prospective randomized trial of the german low-grade lymphoma study group. Cancer 2006, 107:1014-22.

13. Forstpointner R, Unterhalt M, Dreyling M, Bock HP, Repp R, Wandt H, Pott C, Seymour JF, Metzner B, Hanel A, Lehmann T, Hartmann F, Einsele $\mathrm{H}$, Hiddemann $\mathrm{W}$ : Maintenance therapy with rituximab leads to a significant prolongation of response duration after salvage therapy with a combination of rituximab, fludarabine, cyclophosphamide, and mitoxantrone (R-FCM) in patients with recurring and refractory follicular and mantle cell lymphomas: Results of a prospective randomized study of the german low grade lymphoma study group (GLSG). Blood 2006, 108:4003-8.

14. Fisher RI, Dahlberg S, Nathwani BN, Banks PM, Miller TP, Grogan TM: A clinical analysis of two indolent lymphoma entities: Mantle cell lymphoma and marginal zone lymphoma (including the mucosa-associated lymphoid tissue and monocytoid B-cell subcategories): A southwest oncology group study. Blood 1995, 85:1075-82.

15. Howard OM, Gribben JG, Neuberg DS, Grossbard M, Poor C, Janicek MJ, Shipp MA: Rituximab and CHOP induction therapy for newly diagnosed mantle-cell lymphoma: Molecular complete responses are not predictive of progression-free survival. J Clin Oncol 2002, 20: I 288-94.

16. Orlowski RZ, Stinchcombe TE, Mitchell BS, Shea TC, Baldwin AS, Stahl S, Adams J, Esseltine DL, Elliott PJ, Pien CS, Guerciolini R, Anderson JK, Depcik-Smith ND, Bhagat R, Lehman MJ, Novick SC, O'Connor OA, Soignet SL: Phase I trial of the proteasome inhibitor PS-34I in patients with refractory hematologic malignancies. J Clin Oncol 2002, 20:4420-7.

17. Jagannath S, Barlogie B, Berenson J, Siegel D, Irwin D, Richardson PG, Niesvizky R, Alexanian R, Limentani SA, Alsina M, Adams J, Kauffman M, Esseltine DL, Schenkein DP, Anderson KC: A phase 2 study of two doses of bortezomib in relapsed or refractory myeloma. Br J Haematol 2004, I 27: 165-72.

18. Richardson PG, Barlogie B, Berenson J, Singhal S, Jagannath S, Irwin D, Rajkumar SV, Srkalovic G, Alsina M, Alexanian R, Siegel D, Orlowski RZ, Kuter D, Limentani SA, Lee S, Hideshima T, Esseltine DL, Kauffman M, Adams J, Schenkein DP, Anderson KC: A phase 2 study of bortezomib in relapsed, refractory myeloma. $N$ Engl J Med 2003, 348:2609-17.

19. Bross PF, Kane R, Farrell AT, Abraham S, Benson K, Brower ME, Bradley S, Gobburu JV, Goheer A, Lee SL, Leighton J, Liang CY, Lostritto
RT, McGuinn WD, Morse DE, Rahman A, Rosario LA, Verbois SL, Williams G, Wang YC, Pazdur R: Approval summary for bortezomib for injection in the treatment of multiple myeloma. Clin Cancer Res 2004, 10:3954-64.

20. Kane RC, Bross PF, Farrell AT, Pazdur R: Velcade: U.S. FDA approval for the treatment of multiple myeloma progressing on prior therapy. Oncologist 2003, 8:508-13.

21. O'Connor OA, Wright J, Moskowitz C, Muzzy J, MacGregor-Cortelli B, Stubblefield M, Straus D, Portlock C, Hamlin P, Choi E, Dumetrescu O, Esseltine D, Trehu E, Adams J, Schenkein D, Zelenetz AD: Phase II clinical experience with the novel proteasome inhibitor bortezomib in patients with indolent non-hodgkin's lymphoma and mantle cell lymphoma. J Clin Oncol 2005, 23:676-84.

22. Goy A, Younes A, McLaughlin P, Pro B, Romaguera JE, Hagemeister F, Fayad L, Dang NH, Samaniego F, Wang M, Broglio K, Samuels B, Gilles F, Sarris AH, Hart S, Trehu E, Schenkein D, Cabanillas F, Rodriguez AM: Phase II study of proteasome inhibitor bortezomib in relapsed or refractory B-cell non-hodgkin's lymphoma. J Clin Oncol 2005, 23:667-75.

23. Strauss SJ, Maharaj L, Hoare S, Johnson PW, Radford JA, Vinnecombe S, Millard L, Rohatiner A, Boral A, Trehu E, Schenkein D, Balkwill F, Joel SP, Lister TA: Bortezomib therapy in patients with relapsed or refractory lymphoma: Potential correlation of in vitro sensitivity and tumor necrosis factor alpha response with clinical activity. J Clin Oncol 2006, 24:2 I05-I2.

24. Belch A, Kouroukis C. Crump M, Sehn L, Gascoyne R, Klasa R, Powers J, Wright J, Eisenhauer E: A phase II study of bortezomib in mantle cell lymphoma: The national cancer institute of canada clinical trials group trial IND.I50. Ann Oncol 2007 18:||6-2I.

25. Pham LV, Tamayo AT, Yoshimura LC, Lo P, Ford RJ: Inhibition of constitutive NF-kappa B activation in mantle cell lymphoma B cells leads to induction of cell cycle arrest and apoptosis. Immunol 2003, I 7I:88-95.

26. Fu L, Lin-Lee YC, Pham LV, Tamayo A, Yoshimura L, Ford RJ: Constitutive NF-kappaB and NFAT activation leads to stimulation of the BLyS survival pathway in aggressive B-cell lymphomas. Blood 2006, 107:4540-8.

27. Perez-Galan P, Roue G, Villamor N, Montserrat E, Campo E, Colomer D: The proteasome inhibitor bortezomib induces apoptosis in mantle-cell lymphoma through generation of ROS and noxa activation independent of p53 status. Blood 2006, 107:257-64.

28. Karin M: Nuclear factor-kappaB in cancer development and progression. Nature 2006, 441:43I-6.

29. Hayden MS, Ghosh S: Signaling to NF-kappaB. Genes Dev 2004, 18:2195-224.

30. Kim HJ, Hawke N, Baldwin AS: NF-kappaB and IKK as therapeutic targets in cancer. Cell Death Differ 2006, 13:738-47.

3I. Luo JL, Kamata H, Karin M: IKK/NF-kappaB signaling: Balancing life and death - a new approach to cancer therapy. J Clin Invest 2005, I I 5:2625-32.

32. Keutgens A, Robert I, Viatour P, Chariot A: Deregulated NF-kappaB activity in haematological malignancies. Biochem Pharmacol 2006, 72: 1069-80.

33. Shishodia S, Amin HM, Lai R, Aggarwal BB: Curcumin (diferuloylmethane) inhibits constitutive NF-kappaB activation, induces GI/S arrest, suppresses proliferation, and induces apoptosis in mantle cell lymphoma. Biochem Pharmacol 2005, 70:700-13.

34. Ghosh S, Karin M: Missing pieces in the NF-kappaB puzzle. Cell 2002, I09(Suppl):S8I-96.

35. Xiao G, Harhaj EW, Sun SC: NF-kappaB-inducing kinase regulates the processing of NF-kappaB2 pl00. Mol Cell 200I, 7:40I-9.

36. Xiao G, Cvijic ME, Fong A, Harhaj EW, Uhlik MT, Waterfield M, Sun SC: Retroviral oncoprotein tax induces processing of NFkappaB2/pI00 in T cells: Evidence for the involvement of IKKalpha. Embo J 200I, 20:6805-15.

37. Senftleben U, Cao Y, Xiao G, Greten FR, Krahn G, Bonizzi G, Chen Y, Hu Y, Fong A, Sun SC, Karin M: Activation by IKKalpha of a second, evolutionary conserved, NF-kappa B signaling pathway. Science 200I, 293: 1495-9.

38. Han Y, Weinman S, Boldogh I, Walker RK, Brasier AR: Tumor necrosis factor-alpha-inducible IkappaBalpha proteolysis mediated by cytosolic $\mathrm{m}$-calpain. A mechanism parallel to 
the ubiquitin-proteasome pathway for nuclear factor-kappab activation. J Biol Chem 1999, 274:787-794.

39. Baghdiguian S, Martin M, Richard I, Pons F, Astier C, Bourg N, Hay RT, Chemaly R, Halaby G, Loiselet J, Anderson LV, Lopez de Munain A, Fardeau M, Mangeat P, Beckmann JS, Lefranc G: Calpain 3 deficiency is associated with myonuclear apoptosis and profound perturbation of the IkappaB alpha/NF-kappaB pathway in limb-girdle muscular dystrophy type 2A. Nat Med 1999, 5:503-5II.

40. Marcilhac A, Raynaud F, Clerc I, Benyamin Y: Detection and localization of calpain 3-like protease in a neuronal cell line: Possible regulation of apoptotic cell death through degradation of nuclear IkappaBalpha. Int J Biochem Cell Biol 2006, 38:2128-2। 40 .

4I. Canty TG Jr, Boyle EM Jr, Farr A, Morgan EN, Verrier ED, Pohlman TH: Oxidative stress induces NF-kappaB nuclear translocation without degradation of IkappaBalpha. Circulation 1999, 100:I136|-4.

42. Kato $T$ Jr, Delhase M, Hoffmann A, Karin M: CK2 is a C-terminal IkappaB kinase responsible for NF-kappaB activation during the UV response. Mol Cell 2003, 12:829-839.

43. Shumway SD, Berchtold CM, Gould MN, Miyamoto S: Evidence for unique calmodulin-dependent nuclear factor-kappaB regulation in WEHI-23 I B cells. Mol Pharmacol 2002, 61 : I77-85.

44. Miyamoto S, Seufzer BJ, Shumway SD: Novel IkappaB alpha proteolytic pathway in WEHI23 I immature B cells. Mol Cell Biol 1998, 18:19-29.

45. O'Connor S, Shumway SD, Amanna IJ, Hayes CE, Miyamoto S: Regulation of constitutive $\mathrm{p50/c-rel} \mathrm{activity} \mathrm{via} \mathrm{proteasome}$ inhibitor-resistant IkappaBalpha degradation in B cells. Mol Cell Biol 2004, 24:4895-908.

46. Berchtold CM, Chen KS, Miyamoto S, Gould MN: Perillyl alcohol inhibits a calcium-dependent constitutive nuclear factorkappaB pathway. Cancer Res 2005, 65:8558-66.

47. Mori N, Fujii M, Ikeda S, Yamada Y, Tomonaga M, Ballard DW, Yamamoto N: Constitutive activation of NF-kappaB in primary adult T-cell leukemia cells. Blood 1999, 93:2360-8.

48. Davis RE, Brown KD, Siebenlist U, Staudt LM: Constitutive nuclear factor kappaB activity is required for survival of activated $B$ cell-like diffuse large B cell lymphoma cells. J Exp Med 200I, 194:186I-74.

49. Bargou RC, Emmerich F, Krappmann D, Bommert K, Mapara MY, Arnold W, Royer HD, Grinstein E, Greiner A, Scheidereit C, Dorken $B$ : Constitutive nuclear factor-kappaB-RelA activation is required for proliferation and survival of hodgkin's disease tumor cells. J Clin Invest 1997, 100:296I-9.

50. Wang W, Abbruzzese JL, Evans DB, Larry L, Cleary KR, Chiao PJ: The nuclear factor-kappa B RelA transcription factor is constitutively activated in human pancreatic adenocarcinoma cells. Clin Cancer Res 1999, 5:1 19-27.

5I. Zerbini LF, Wang Y, Cho JY, Libermann TA: Constitutive activation of nuclear factor kappaB p50/p65 and fra-I and JunD is essential for deregulated interleukin 6 expression in prostate cancer. Cancer Res 2003, 63:2206-I5.

52. Duffey DC, Chen Z, Dong G, Ondrey FG, Wolf JS, Brown K, Siebenlist U, Van Waes C: Expression of a dominant-negative mutant inhibitor-kappaBalpha of nuclear factor-kappaB in human head and neck squamous cell carcinoma inhibits survival, proinflammatory cytokine expression, and tumor growth in vivo. Cancer Res 1999, 59:3468-74.

53. Sovak MA, Bellas RE, Kim DW, Zanieski G], Rogers AE, Traish AM, Sonenshein GE: Aberrant nuclear factor-kappaB/Rel expression and the pathogenesis of breast cancer. J Clin Invest 1997, 1 00:2952-60.

54. Annunziata CM, Davis RE, Demchenko $Y$, Bellamy W, Gabrea A, Zhan F, Lenz G, Hanamura I, Wright G, Xiao W, Dave S, Hurt EM, Tan B, Zhao H, Stephens O, Santra M, Williams DR, Dang L, Barlogie $B$, Shaughnessy JD Jr, Kuehl WM, Staudt LM: Frequent engagement of the classical and alternative NF-kappaB pathways by diverse genetic abnormalities in multiple myeloma. Cancer Cell 2007, I 2:1115-130.

55. Keats J], Fonseca R, Chesi M, Schop R, Baker A, Chng WJ, Van Wier S, Tiedemann R, Shi CX, Sebag M, Braggio E, Henry T, Zhu YX, Fogle $\mathrm{H}$, Price-Troska T, Ahmann G, Mancini C, Brents LA, Kumar S, Greipp P, Dispenzieri A, Bryant B, Mulligan G, Bruhn L, Barrett M, Valdez R, Trent J, Stewart AK, Carpten J, Bergsagel PL: Promiscuous mutations activate the noncanonical NF-kappaB pathway in multiple myeloma. Cancer Cell 2007, I 2:131- I44

56. Fields ER, Seufzer BJ, Oltz EM, Miyamoto S: A switch in distinct I kappa B alpha degradation mechanisms mediates constitutive NF-kappa B activation in mature B cells. J Immunol 2000, 164:4762-7.

57. O'Connor S, Markovina S, Miyamoto S: Evidence for a phosphorylation-independent role for ser 32 and 36 in proteasome inhibitor-resistant (PIR) IkappaBalpha degradation in B cells. Exp Cell Res 2005, 307:15-25.

58. Shumway SD, Miyamoto S: A mechanistic insight into a proteasome-independent constitutive inhibitor kappaBalpha (IkappaBalpha) degradation and nuclear factor kappaB (NFkappaB) activation pathway in WEHI-23 I B-cells. Biochem J 2004, 380: 173-80.

59. Nakamura Y, Grumont RJ, Gerondakis S: NF-kappaB I can inhibit $\mathrm{v}$-abl-induced lymphoid transformation by functioning as a negative regulator of cyclin DI expression. Mol Cell Biol 2002, 22:5563-5574.

60. Gould MN: Cancer chemoprevention and therapy by monoterpenes. Environ Health Perspect 1997, 105(Suppl 4):977-979.

61. Salaverria I, Perez-Galan P, Colomer D, Campo E: Mantle cell lymphoma: From pathology and molecular pathogenesis to new therapeutic perspectives. Haematologica 2006, 9 I: I I-6.

62. Miyamoto S, Schmitt MJ, Verma IM: Qualitative changes in the subunit composition of kappa B-binding complexes during murine B-cell differentiation. Proc Natl Acad Sci USA 1994, 91:5056-60.

63. Zamai L, Falcieri E, Marhefka G, Vitale M: Supravital exposure to propidium iodide identifies apoptotic cells in the absence of nucleosomal DNA fragmentation. Cytometry 1996, 23:303-II.

64. Chou TC, Talalay P: Quantitative analysis of dose-effect relationships: The combined effects of multiple drugs or enzyme inhibitors. Adv Enzyme Regul 1984, 22:27-55.

65. Chou TC, Talalay P: Generalized equations for the analysis of inhibitions of michaelis-menten and higher-order kinetic systems with two or more mutually exclusive and nonexclusive inhibitors. Eur J Biochem 1981, I I 5:207-216.

66. Herrero JA, Mathew P, Paya CV: LMP-I activates NF-kappa B by targeting the inhibitory molecule I kappa B alpha. J Virol I995, 69:2।68-74

67. Haag JD, Gould MN: Mammary carcinoma regression induced by perillyl alcohol, a hydroxylated analog of limonene. Cancer Chemother Pharmacol 1994, 34:477-483.

68. Mills IJ, Chari RS, Boyer I], Gould MN, Jirtle RL: Induction of apoptosis in liver tumors by the monoterpene perillyl alcohol. Cancer Res 1995, 55:979-983.

69. Stark MJ, Burke YD, McKinzie JH, Ayoubi AS, Crowell PL: Chemotherapy of pancreatic cancer with the monoterpene perillyl alcohol. Cancer Lett 1995, 96:15-21.

70. Xu M, Floyd HS, Greth SM, Chang WC, Lohman K, Stoyanova R, Kucera GL, Kute TE, Willingham MC, Miller MS: Perillyl alcoholmediated inhibition of lung cancer cell line proliferation: Potential mechanisms for its chemotherapeutic effects. Toxicol Appl Pharmacol 2004, 195:232-246.

7I. Ryan DP, Appleman LJ, Lynch T, Supko JG, Fidias P, Clark JW, Fishman M, Zhu AX, Enzinger PC, Kashala O, J C Jr, Eder JP: Phase I clinical trial of bortezomib in combination with gemcitabine in patients with advanced solid tumors. Cancer 2006, 107:2482-9.

72. Papandreou CN, Daliani DD, Nix D, Yang H, Madden T, Wang $X$, Pien CS, Millikan RE, Tu SM, Pagliaro L, Kim J, Adams J, Elliott P, Esseltine D, Petrusich A, Dieringer P, Perez C, Logothetis Cl: Phase I trial of the proteasome inhibitor bortezomib in patients with advanced solid tumors with observations in androgen-independent prostate cancer. J Clin Oncol 2004, 22:2 I08-21.

73. Richardson PG, Mitsiades C, Hideshima T, Anderson KC: Bortezomib: Proteasome inhibition as an effective anticancer therapy. Annu Rev Med 2006, 57:33-47.

74. Crowell PL, Chang RR, Ren ZB, Elson CE, Gould MN: Selective inhibition of isoprenylation of $2 \mathrm{I}-26-\mathrm{kDa}$ proteins by the anticarcinogen d-limonene and its metabolites. J Biol Chem 1991, 266: 17679-17685.

75. Stayrook KR, McKinzie JH, Barbhaiya LH, Crowell PL: Effects of the antitumor agent perillyl alcohol on H-ras vs. K-ras farnesylation and signal transduction in pancreatic cells. Anticancer Res 1998, 18:823-828. 
76. Sherr CJ, Roberts JM: Inhibitors of mammalian GI cyclindependent kinases. Genes Dev 1995, 9: I I49-II63.

77. Alexandrow MG, Moses HL: Transforming growth factor beta and cell cycle regulation. Cancer Res 1995, 55:|452-I 457.

78. Hideshima T, Mitsiades C, Akiyama M, Hayashi T, Chauhan D, Richardson P, Schlossman R, Podar K, Munshi NC, Mitsiades N, Anderson $\mathrm{KC}$ : Molecular mechanisms mediating antimyeloma activity of proteasome inhibitor PS-34I. Blood 2003, 101:1530-4.

79. Mitsiades N, Mitsiades CS, V P, Chauhan D, Fanourakis G, Gu X, Bailey C, Joseph M, Libermann TA, Treon SP, Munshi NC, Richardson PG, Hideshima T, Anderson KC: Molecular sequelae of proteasome inhibition in human multiple myeloma cells. Proc Natl Acad Sci USA 2002, 99:14374-9.

80. Ling YH, Liebes L, Jiang JD, Holland JF, Elliott PJ, Adams J, Muggia FM, Perez-Soler R: Mechanisms of proteasome inhibitor PS-34Iinduced G(2)-M-phase arrest and apoptosis in human nonsmall cell lung cancer cell lines. Clin Cancer Res 2003, 9: I | 45-54.

81. Fribley A, Zeng Q, Wang CY: Proteasome inhibitor PS-34I induces apoptosis through induction of endoplasmic reticulum stress-reactive oxygen species in head and neck squamous cell carcinoma cells. Mol Cell Biol 2004, 24:9695-704.

82. Fribley AM, Evenchik B, Zeng Q, Park BK, Guan JY, Zhang H, Hale TJ, Soengas MS, Kaufman RJ, Wang CY: Proteasome inhibitor PS-34I induces apoptosis in cisplatin-resistant squamous cell carcinoma cells by induction of noxa. J Biol Chem 2006, 281:31440-7.

\section{Publish with Bio Med Central and every scientist can read your work free of charge}

"BioMed Central will be the most significant development for disseminating the results of biomedical research in our lifetime. "

Sir Paul Nurse, Cancer Research UK

Your research papers will be:

- available free of charge to the entire biomedical community

- peer reviewed and published immediately upon acceptance

- cited in PubMed and archived on PubMed Central

- yours - you keep the copyright

Submit your manuscript here:

http://www.biomedcentral.com/info/publishing_adv.asp 